\title{
PENDEKATAN KONSELING DENGAN CBT (COGNITIVE BEHAVIOR THERAPY) DALAM MENINGKATKAN MOTIVASI PENDERITA KUSTA MENJALANI PENGOBATAN
}

\author{
Haris Jamaludin*, Uus Husni**Ira Farida Sari***
}

\begin{abstract}
ABSTRAK
Penyakit kusta di Indonesia semakin hari semakin bertambah. Desa Blandongan wilayah kerja Puskesmas Bandungsari Kecamatan Banjarharjo Kabupaten Brebes merupakan Desa dengan penyebaran kusta terbanyak di Provinsi Jawa Tengah. Pesatnya penyebaran penderita kusta ini penyebabnya adalah kurang keinginan penderita kusta akan pentingnya pengobatan kusta, menjalani pengobatan kusta yang teratur dan konseling dengan tenaga Kesehatan atau Puskesmas mengenai penyakit kusta sehingga proses eliminasi kusta belum tercapai.Tujuan dalam penelitian ini untuk mengetahui bagaimana pendekatan konseling dengan CBT dalam meningkatkan motivasi penderita kusta menjalani pengobatan. Penelitian ini menggunakan metode kualitatif dengan pendekatan fenomenologi (deskriptif), dimana jumlah subjek tiga orang yang ditentukan dengan purposive sampling, dan data dikumpulkan dengan wawancara dan observasi langsung pada responden selama 3 minggu. Hasil penelitian didapatkan bahwa penderita kusta yang telah melakukan konseling dengan CBT (Cognitive Behavior Therapy) merasakan lebih termotivasi untuk menjalani pengobatan secara teratur dan dapat sembuh, dimana sebelumnya penderita kusta tidak teratur minum obat dan kurangnya pengetahuan maupun pemahaman penyakit kusta.
\end{abstract}

Kata Kunci : Kusta, Kualitatif, motivasi berobat

\begin{abstract}
Leprosy in Indonesia is increasingly improved. Countryside Health Center jobs Blandongan region Bandungsrai Sub Banjarharjo Brebes Regency Village with the spread of infection is highest in Central Java Province. The rapid spread of leprosy sufferers this cause is less desire leprosy patients on the importance of treatment of leprosy, a disease undergoing regular treatment and counseling of energy or Health Centers of leprosy until a process of elimination of leprosy has not been achieved. The goal in this study to determine how to approach counseling with CBT in Enhancing motivation leprosy patients undergoing treatment. This study used a qualitative method with a phenomenological approach (descriptive), where the number of subjects is determined by three people who purposive sampling, and data were collected by interview and direct observation on the respondent for 3 weeks. The results showed that patients with leprosy who had done counseling with CBT (Cognitive Behavior Therapy) feel more motivated to undergo treatment on a regular basis and can be cured, where leprosy patients not previously taking the medication regularly and lack of knowledge and understanding of leprosy.
\end{abstract}

Keywords : Leprosy, Qualitative, motivation for treatment

\footnotetext{
* Alumni PSIK STIKes Cirebon Lulus Tahun 2014

** Staf Pengajar Program Studi S1 Keperawatan STIKes Cirebon

***Staf Pengajar Parogram Studi S1 Keperawatan STIKes Cirebon
} 


\section{PENDAHULUAN}

Permasalahan penyakit kusta yang sangat komplek terkait dengan kehidupan klien kusta yang terjadi secara fisik, psikologis, dan sosial. Permasalahan fisik penyakit kusta terkait dengan lesi pada kulit dan kecacatan fisik. Dimasyarakat penanganan penyakit kusta memerlukan penanganan secara psikologis maupun fisik. Permasalahan psikologis kusta akan mengakibatkan gangguan interaksi sosial pada penderitanya akibat pandangan yang negatif dari masyarakat terkait penyakit kusta dan akan membuat penderita kusta mengalami penurunan motivasi dalam menjalani pengobatan. ${ }^{1}$

Kendala atau masalah pengobatan kusta terjadi karena kondisi ekonomi masyarakat dan kepatuhan menjalani pengobatan yang masih rendah, akibatnya banyak penderita kusta yang droup out dari pengobatan tersebut. Pengobatan kusta untuk tipe PB membutuhkan waktu 6-9 bulan, sedangkan tipe MB membutuhkan waktu 12-18 bulan, maka biasanya memiliki resiko tinggi dalam ketidak patuhan berobat dan minum obat. Ketaatan atau kepatuhan minum obat pada penderita kusta dipengaruhi lamanya masa pengobatan dan kurangnya motivasi penderita kusta menjalani pengobatan, sehingga diperlukan keuletan dan ketekunan. Timbul rasa bosan, perasaan sudah sembuh mengakibatkan penderita kusta menghentikan pengobatan sebelum masa akhir pengobatan selesai. ${ }^{1}$

Prevalensi di Indonesia sebesar 0,98 per 10.000 penduduk berdasarkan laporan WHO tahun 2005. Prevalensi tersebut menunjukkan Indonesia telah berhasil melakukan program eliminasi kusta yang ditetapkan oleh WHO yaitu 1 per 10.000 penduduk. Tetapi di beberapa propinsi di Indonesia masih belum mencapai angka program eliminasi tersebut dan sangat berisiko terhadap penyakit kusta. Indonesia memiliki 14 propinsi yang menjadi daerah resiko penyakit kusta dengan kasus lebih dari 10.000 kasus yaitu Jawa Tengah, Irian Jaya bagian barat, Papua, Jawa Timur, Jawa Barat, Sulawesi Tenggara, Sulawesi Barat, Sulawesi Utara, Maluku, Maluku Utara, NTT, NTB, Aceh, dan DKI Jakarta. ${ }^{2}$

Penemuan penderita baru di Jawa Tengah masih tinggi. Jawa Tengah menempati urutan ke 15. Tahun 2007 di Jawa Tengah terdapat 1.850 penderita kusta terdaftar, terdiri dari tipe PB : 166 penderita dan tipe MB : 1.684 penderita, PR : 0,58/10.000, CDR : 0,21/10.000, proporsi cacat tingkat $2: 14,1 \%$, dan penderita kusta $9,8 \%{ }^{3}$

Data program kusta Puskesmas Bandungsari tahun 2012-2014, didapatkan jumlah penderita kusta yang terdaftar sebanyak 15 orang. Penderita kusta jenis PB sebanyak 3 orang dan MB sebanyak 12 orang. Prevalance rate kusta di Puskesmas Bandungsari per Desa adalah 3 orang per 10.000 penduduk. Angka Prevalance rate di Desa Blandongan wilayah kerja Puskesmas Bandungsari masih melebihi angka program eliminasi kusta. Data Puskesmas Bandungsari untuk Desa Blandongan sampai awal bulan Maret 2014, penderita kusta yang dibina sebanyak 15 orang. Penderita yang mengalami penurunan motivasi dalam menjalani pengobatan sebanyak 5 orang. Hal ini menunjukan masih belum optimalnya kegiatan pengawasan menjalani pengobatan, konseling dengan petugas kesehatan dan masih rendahnya motivasi penderita kusta dalam menjalani pengobatan. ${ }^{4}$

Untuk mencapai keberhasilan pengobatan dibutuhkan motivasi pada diri pasien dan kesembuhan,baik dari lingkungan, keluarga dan penderita khususnya, motivasi inilah yang menjadi daya penggerak dalam diri individu sebagai upaya untuk mencari jalan keluar. Pasien dengan motivasi tinggi akan cepat pulih dari penyakitnya. ${ }^{5}$

Salah satu pendekatan yang efektif untuk mengatasi rendahnya motivasi dalam menjalani pengobatan pada penderita kusta adalah Cognitive Behavior Therapy (CBT). CBT (Cognitive Behavior Therapy) meyakini bahwa proses kognisi seperti pikiran, interprestasi, persepsi, dan keyakinan memiliki pengaruh terhadap respon, perilaku, dan emosi individu. ${ }^{6}$ CBT terbukti efektif untuk mengatasi berbagai macam masalah psikologis. Selain itu juga CBT bekerja secara cepat dan dapat dipertanggung jawabkan meski dilakukan dalam waktu singkat. CBT (Cognitive Behavior Therapy) merupakan salah satu pendekatan yang lebih 
integratif dalam konseling untuk merubah atau meningkatkan motivasi dalam menjalani pengobatan. ${ }^{7} \mathrm{CBT}$ didasarkan pada konsep mengubah pikiran dan perilaku negatif yang sangat mempengaruhi emosi. Melalui CBT, konseli terlibat aktivitas dan berpartisipasi dalam training untuk diri dengan cara membuat keputusan, penguatan diri dan strategi. ${ }^{8}$

Tujuan dalam penelitian ini untuk mengetahui pendekatan konseling dengan Cognitive Behavior Therapy (CBT) dan motivasi penderita kusta dalam menjalani pengobatan di Desa Blandongan Wilayah Kerja Puskesmas Bandungsari Kecamatan Banjarharjo Kabupaten Brebes Tahun 2014.

\section{METODE PENELITIAN}

Penelitian ini menggunakan metode penelitian kualitatif. Metode penelitian kualitatif dipilih sebagai suatu pendekatan dalam penelitian ini karena penelitian ini mencoba untuk menggali arti dan makna klien kusta dalam menjalani pengobatan. Permasalahan motivasi penderita kusta yang kurang dalam menjalani pengobatan digali dengan menggunakan metode penelitian kualitatif melalui pendekatan fenomenologi.

Populasi sebagai situasi sosial dalam penelitian ini adalah klien kusta yang berada di Desa Blandongan dan menjalani pengobatan di Puskesmas Bandungsari berjumlah lima belas orang.

Teknik pengambilan sampel dalam penelitian kualitatif menggunakan sampel bertujuan (purposive sampling) yaitu suatu teknik yang didasarkan pada tujuan penelitian. Pada penelitian ini peneliti menetapkan jumlah sampel sebanyak 3 partisipan. Data diambil Dari 3 partisipan dengan karakteristik sesuai kriteria inklusi yang ditetapkan yaitu pasien kusta yang pernah menjalani Konseling Cognitive Behavior Therapy (CBT) di Desa Blandongan Wilayah Kerja Puskesmas Bandungsari Kecamatan Banjarharjo Kabupaten Brebes, Pasien kusta yang belum mengalami luka kronis dan mampu berkomunikasi dengan baik.

Alat pengumpulan data yang digunakan untuk menunjang pengumpulan data dalam penelitian ini adalah pedoman wawancara, catatan lapangan (filed notes), kamera handphone dan alat perekam suara (handphone). Teknik wawancara dalam penelitian pendekatan kualitatif dibagi menjadi tiga kategori, yaitu : Informal conversational interview, General interview guide approach, dan Standardized opend-ended interview Informal conversational interview.

Analisis data dalam studi kualitatif didasarkan pada penafsiran data. Peneliti menafsirkan setiap informasi yang didapatkan dari partisipan dan mencoba menyimpulkan beberapa informasi yang sesuai dengan tujuan dari penelitian. Peneliti mengumpulkan sejumlah data yang sangat besar yang kemudian dikurangi menjadi suatu pola tertentu, kategori atau tema.

\section{HASIL PENELITIAN}

\section{Karakteristik Informan}

Informan dalam penelitian ini berjumlah tiga orang dan sedang menjalani pengobatan di Puskesmas Bandungsari Kecamatan Banjarharjo Kabupaten Brebes. Informan yang berjenis kelamin laki-laki sebanyak dua orang dan yang perempuan berjumlah satu orang. Usia informan bervariasi, yaitu antara usia empat puluh lima tahun sampai dengan enam puluh lima tahun. Tingkat pendidikan informan ada yang tidak sekolah dan ada juga yang tidak tamat Sekolah Dasar (SD), pekerjaan informan mayoritas petani walaupun ada satu informan yang pekerjaanya terkadang petani dan terkadang merantau ke kota. Seluruh Informan berasal dari suku Sunda.

Dari ketiga informan lama menjalani pengobatan kusta mulai dari empat bulan sampai dengan sebelas bulan. Selama informan menjalani pengobata, informan mendapatkan paket MDT. Anggota keluarga yang berpartisipasi dalam pengobatan informan adalah suami, istri, 
dan anaknya dan informan semuanya tinggal bersama keluarganya. Informan menderita penyakit kusta tipe MB (Multi Baciller) atau kusta basah.

\section{Pendekatan Konseling dengan CBT (Cognitive Behavior Therapy)}

Konseling ini sangat berkaitan erat dengan keterbukaanya penderita kusta terhadap apa yang dirasakan saat ini, mengetahui positif terkena penyakit kusta dan selama menjalani pengobatan, apakah setelah partisipan melakukan konseling dengan CBT (Cognitive Behavior Therapy) ini motivasinya meningkat ataukan motivasi partisipan menurun. Karena motivasi ini sangat berkaitan dengan berhasil atau tidaknya pengobatan kusta ini, motivasi ini sangat membantu dalam kesembuhan penyakit kusta, karena tanpa motivasi yang tinggi penyakit kusta ini kemungkinan sembuhnya kecil. Pengobatan kusta ini memerlukan pengobatan yang lama terutama penyakit kusta tipe MB (Multi Baciller) yang harus menjalani pengobatan antara 12-18 bulan.

\section{Meningkatnya motivasi}

Informan dalam penelitian ini juga melakukan konseling dengan CBT dengan petugas kesehatan dan menunjukan motivasinya meningkat, yang didukung oleh pernyataan ketiga informan sebagai berikut ini:

"iya kalau menurut saya kegiatan konseling ini bisa meningkatkan motivasi, yang tadinya tidak tahu mengenai penyakit kusta menjadi tahu, di kasih tahu juga pengobatannya bagaimana dan harus bagaimana selama pengobatan. Jadi menurut saya kegiatan konseling dengan CBT ini bisa di lanjutkan, jangan hanya sekali dua kali saja, soalnya kegiatan konseling ini bisa meningkatkan motivasi saya dalam menjalani pengobtan dan saya harapkan kegiatan konseling ini terus dilakukan, baik untuk penyakit kusta maupun penyakit yang lainnya" (I.1, I.2 \& I.3)

\section{Menurunnya motivasi}

Informan dalam penelitian ini juga melakukan konseling dengan CBT dengan petugas kesehatan dan tidak menunjukan penurunan motivasi menjalani pengobatan, akan tetapi informan justru lebih semangat dalam menjalani pengobatan.

\section{Persepsi Terhadap Penyakit Kusta}

Informan mempersepsikan penyakit kusta berkaitan dengan gambaran dari penyakit tersebut. Informan memberikan gambaran penyakit, dapat memahami penyakit kusta secara baik ataupun kurang baik. Hal ini berkaitan dengan pengetahuan dan informasi yang dimiliki oleh informan terkait kondisinya saat ini sehigga akan memberikan pemahaman gambaran penyakit yang baik ataupun kurang baik. Di jelaskan di bawah ini:"Iya paling ini, penyakit kusta, tanda-tandanya seperti panu, putih, bening dan tidak gatal, akan tetapi bisa diobati lama" (I.1, I.2 \& I.3)

Informan dengan latar belakang sudah lebih dari empat bulan menjalani pengobatan kusta dan memperoleh informasi yang baik mengenai kusta dari petugas Puskesmas, akan mempersepsikan penyakit kusta dan memahaminya secara baik. Tiga orang informan dalam penelitian ini memberikan gambaran mengenai penyakit kusta yang digambarkan sebagai kondisi penyakit yang sedang diderita oleh partisipan. Informan dalam memberikan gambaran penyakit tersebut dapat baik berdasarkan prihal yang dialami yang didukung oleh pernyataan informan berikut ini:

“...iya kalau penyakit kusta ini luka sedikit juga tidak kerasa, tapi kalau diobatinya telat nanati bisa menular......" (I.1 dan I.3) 
“...saya kalau penyakit seperti ini langsung terus diobati cepet-cepet diobati, ya kalau sembuh si tidak, tapi kan tidak menular, kalau penyakit ini dibiarkan terus dang a cepat-cepat diobati nantinya menjalar kemana-mana..” (I.1, I.2 \& I.3)

Informan dalam penelitian ini juga mempersepsikan penyakit kusta dengan memahaminya secara kurang baik. Pemahaman informan yang kurag baik ini berkaitan dengan kemampuan informan kusta dalam memberikan gambaran penyakit yang kurang tepat. Satu orang informan yang memberikan gambaran penyakit yang kurang tepat dalam penelitian ini berkaitan dengan kurangnya pemahaman dari informan yang berkaitan dengan penyakitnya, yang didukung oleh pernyataan partisipan sebagai berikut ini:

“...ini penyakit kulit pokoknya, ya saya paham ini penyakit kulit, ini tidak menular..." (I.2)

\section{Pengobatan Kusta (Keteraturan atau Kepatuhan Minum Obat MDT)}

Persepsi dan motivasi informan dalam menjalani pengobatan kusta ditemukan tema yaitu tetang kepatuhan minum MDT. Kepatuhan informan dalam menjalani pengobatan dalam penelitian ini ada yang patuh maupun ada yang tidak patuh terhadap pemberian obat. Hal ini berhubungan dengan ketidaktahuan dan ketidaknyamanan atau keluhan yang dialami oleh informan terhadap efek samping yang ditimbukan oleh pengobatan tersebut.

Informan yang patuh terhadap pengobatan kusta dalam penelitian ini ditunjukan melalui mentatai aturan pemberian obat. Informan dalam mentatati pemberian obat kusta berkaitan dengan waktu minum obat, pengambilan obat, dan dampak positif pengobatan kusta yang diterimanya. Informan dalam penelitian ini juga mengalami ketidakpatuhan terhadap menjalani pengobatan. Satu orang informan melanggar minum obat kusta berkaitan dengan ketidaktahuan informan terhadap tanda dan gejala kesembuhan penyakit kusta yang didukung dengan pernyataan informan berikut ini:

".... iyah saya pernah berhenti minum obat, kalau tidak salah berhentinya lima belas hari, di karenakan saya merasa sembuh, padahal obatnya masih, karena saya merasa sembuh akhirnya saya berhenti minum obat dan saya juga tidak tahu kalau ternyata penyakit kusta ini tidak sama dengan penyakit lain, kalau sudah tidak ada yang di rasakan sudah sembuh, tapi kata saudara saya jangan berhenti minum obat sampai satu tahun atau sebelum kata pihak Puskesmas suruh berhenti...." (I.2)

\section{Dukungan Keluarga}

Dalam penelitian ini informan mendapatkan dukungan dari keluarga, sehingga pengobatan yang di jalani informan berjalan dengan baik, karena tanpa adanya dukungan dari keluarga pengobatan kusta yang memerlukan waktu yang lama akan terhambat, dukungan keluarga ini juga mempengaruhi akan keberhasilan pengobatn dan tercapainya kesembuhan informan.

\section{Peran Perawat}

Harapan informan terhadap peran perawat dalam penelitian ini adalah adanya suatu bentuk dukungan perawat. Dukungan perawat yang diinginkan partisipan tersebut berkaitan dengan peran perawat.

Pernyataan partisipan yang menggambarkan peran perawat diungkapkan oleh kedua informan berikut ini:

"..alhamdulilah pa mantri (perawat) mau ke rumah saya memberi dukungan, konseling dan motivasi..." (I.1, I.2 \& I.3) 


\section{PEMBAHASAN}

\section{Pendekatan Konseling dengan CBT (Cognitive Behavior Therapy)}

Dalam penelitian ini seluruh informan pernah melakukan Konseling dengan CBT (Cognitive Behavior Therapy) untuk membantu partisipan dalam proses pengobatan yang sedang dijalani. Konseling merupakan bagian dari bimbingan baik sebagai pelayanan maupun sebagai teknik. Konseling merupakan inti kegiatan bimbingan secara keseluruhan dan lebih berkenaan dengan masalah individu secara pribadi. Mortensen (1964:301, dalam M. Surya, 2003) mengatakan bahwa "counselling is the heart of the guidance program". Dan Ruth Strang (1958) dalam M. Surya (2003) menyatakan bahwa "guidance is broader: counselling is a most important tool of guidance". 9

Jadi konseling merupakan inti dan alat yang penting dalam keseluruhan sistem dan kegiatan bimbingan. Jadi dalam kegiatan konseling ini partisipan di ajak untuk melihat dan menatap ke masa depan, partisipan di beri arahan bahwa penyakit yang dideritanya ini bisa di sembuhkan, dengan catatan partisipan mengikuti aturan da ajuran petugas kesehatan. Brammer \& Shostrom (1982:8): Menekankan konseling sebagai suatu perencanaan yang lebih rasional, pencegahan terhadap munculnya masalah penyesuaian diri, dan memberi dukungan dalam menghadapi tekanan-tekanan situasional dalam kehidupan sehari-hari bagi orang normal. Sutarno, 2003, adapun tujuan kegiatan konseling dengan CBT (Cognitive Behavior Therapy) adalah membantu klien mengembalikan klien ke dalam masyarakat, meningkatkan motivasi klien, membenahi tingkah laku yang menyimpang dan membantu klien mengembangkan system self management dan self control. ${ }^{9}$

\section{Pengetahuan Terhadap Penyakit Kusta}

Klien dalam penelitian ini juga memprsepsikan penyakit kusta memahaminya secara kurang baik. Pemahaman klien yang kurang baik ini berkaitan dengan kemampuan klien kusta dalam memberikan gambaran penyakit yang kurang tepat. Ketidaktepatan klien dalam memberikan gambaran penyakitnya tersebut akibat kurangnya pemahaman dari klien yang berkaitan dengan penyakitnya. Klien kusta dalam penelitian ini mempersepsikan gambaran penyakit kusta berkaitan dengan tingkat pengetahuan dan pemahaman kien terhadap penyakit kusta yang dialaminya serta umumnya klien memiliki tingkat pendidikan yang redah. Kosasih (1997) mengidentifikasi tingkat pendidikan secara kuantitaif berpengaruh terhadap pengetahuan kepala keluarga dan tokoh masyarakat tentang kusta di Kabupaten Kuningan Propinsi Jawa Barat tahun 1996. ${ }^{10}$

Pengetahuan tentang kusta dalam penelitian ini merupakan respon awal yang dimiliki oleh klien terkait dengan apa yang dirasakan dan dialami oleh dirinya selama sakit. Pengetahuan klien tentang kusta dalam penelitian ini teridentifikasi ada sebagain partisipan yang mengetahui dirinya menderita penyakit kusta dan sebagian partisipan yang tidak mengetahui kusta yang umumnya sudah berkaitan dengan persepsi dari penyakit yang dialami oleh klien. Pitchard (1986) persepsi merupakan gambaran subyektif internal seseorang terhadap dunia luarnya. Faktor yang berperan dalam pembentukan persepsi adalah kognitif, afektif, kepribadian dan budaya yang dimiliki seseorng yang berasal dari kenyataan yang ada di lingkunganya, pengalaman dimasa lalu, serta keadaan mutakir dari emosi maupun motivasi seseorang. ${ }^{11}$

Roenstock (dalam; Glanz et all, 1990; dan Sarafino, 1994) menyatakan bahwa persepsi dipengaruhi oleh variabel demografis seperti umur, ras, pendidikan, dan variabel psikososial sperti status sosial, tekanan sosial, dan variabel struktural seperti pengethauan masalah kesehatan atau riwayat kontak dengan masalah kesehatan tersebut. Penegetahuan klien kusta tentang maalah kusta ataupun riwayat kontak dengan dengan permasalahan kusta dalam penelitian ini mengakibatkan klien kusta untuk membuat keputusan yang berkaitan dengan manajemen pengobatan yang akan dijalaninya dalam mencapai kesembuhan. ${ }^{10}$ 


\section{Pengobatan MDT}

Kepatuhan klien terhadap pengobatan kusta dalam penelitian ini ditunjukan melalui mentaati aturan pemberian obat. Klien kusta dalam mentaati pemberian obat kusta berkaitan dengan waktu minum obat dan dampak positif pengobatan kusta yag diterimnya. Kepatuhan klien dalam minum obat MDT menunjukan terapeutik yang efektif pada pengobatan kusta. NANDA (2002) terapeutik yang efektif merupakan pola pengaturan dan integrasi dalam program latihan sehari-hari untuk orang sakit dan latihan berkelanjutan yang memuaskan untuk mendapatkan tujuan spesifik. ${ }^{11}$

Klien kusta yang mematuhi aturan minum obat MDT dalam penelitian ini juga didukung oleh adanya dampak positif dari pengobatan kusta. Hardyanto dalam saranani (2005; dalam hutabarat, 2008) pengobatan kusta yang adekuat dan keteraturan minum obat akan mengurangi kondisi yang infeksius dari klien kusta yang menular, ketidakteraturan dan ketidaktaatan minum obat pada klien kusta akan berakibat sangat buruk yang berdampak terhadap kondisi resistensi obat-obatan anti kusta pada klien kusta. Kondisi resistensi obat anti kusta pada klien kusta sebagai akibat dari ketidak patuhan klien kusta terhadap pengobatan yang diberikan.

Klien kusta menjalani pengobatan kusta dalam peneitian ini mengalami ketidak patuhaan terhadap pengobatan. Ketidak patuhan klien terhadap pengobatan kusta ditunjukan melalui perilaku melanggar aturan minum obat. Klien kusta dalam melanggar aturan minum obatkkusta dalam penelitian ini berkaitan dengan kurang percaya diri terhadap pengobatan dan ketidak tahuan klien kusta. Oesman (1993) faktor yang mempunyai peran besar dalam keteraturan berobat adalah kepercayaan penderita $(85,76 \&)$ dan kelainan kulit penderita kusta (86,42\&) di Kabupate Tanggerang 1989-1991. ${ }^{10}$

Kurangnya kepercayaan klien dan ketidak tahuaan klien terhadap pengobatan kusta dalam penelitian ini mengakibatkan tidak efektifnya terapeutik pengobatan kusta. NANDA (2002) terapeutik yang tidak efektif merupakan pola pengaturan dan integrasi kedalam program latiham aktivitas sehari-hari bagi orag sakit dan latihan berkelanjutan yang menimbulkan ketidak patuhan untuk menemukan tujuan kesehtan spesifik.

Klien kusta tidak patuh berobat dalam penelitian ini karena klien tidak tahu akan tanda kesembuhan penyakitnya. Kepatuhan klien kusta menjalani pengobatan dalam penelitian ini juga berkaitan dengan efek samping dari pemberian obat. Sebagian klien kusta yang mengalami ketidaknyamanan terhadap efek samping pengobatan dalam penelitian ini mengalami ketidakpatuhan dalam berobat. Hal ini berbeda dengan penelitian Hutabarat (2008) yang menyatakan tidak ada hubungan efek samping obat dengan kepatuhan minum obat atau menjalani pengobatan pada penderita kusta $(58,1 \%)$ di Kabuoaten Ashan tahun 2007. ${ }^{10}$

\section{SIMPULAN}

Berdasarkan hasil penelitian dan uraian pembahasan pada bab sebelumnya dimana penderita menyatakan telah melakukan sesi konseling dengan CBT oleh petugas kesehatan dan tidak hanya sekali, menjadi termotivasi untuk tetap menjalani pengobatan secara teratur untuk dapat sembuh. Hal ini dapat disimpulkan bahwa pendekatan konseling dengan CBT jika dilakukan dengan baik dapat membantu meningkatkan motivasi penderita untuk dapat menjalani pengobatan dengan benar.

\section{SARAN}

1. Bagi Puskesmas Bandungsari

Diharapkan kegiatan konseling dengan CBT ini terus dilanjutkan oleh Puskesmas dan dijadikan sebagai program Puskesmas, melihat dari hasil penelitian di atas, kegiatan konseling ini cukup berperan terhadap keteraturan pengobatan yang dijalani oleh penderita 
kusta dan dari kegiatan konseling ini Puskesmas bisa mengetahui bagaimana keadaan dan bagaimna perasaan penderita kusta ini selama menjalani pengobatan.

2. Bagi Penderita kusta

Diharapkan Informan mampu untuk memotivasi dirinya sendiri setelah melakukan konseling dengan CBT (Cognitive Behavior Therapy), melihat motivasi ini sangat berperan penting terhadap kesembuhan penderita kusta itu sendiri, karena kalu motivasi dalam menjalani pengobatan rendah, secara otomatis pengobatanpun akan terhambat.

3. Bagi Profesi Keperawatan

Diharapkan kegiatan ini bisa dilakukan oleh seluruh perawat, melihat konseling ini merupakan kegiatan yang bisa membantu dalam meningkatkan kesembuhan dan motivasi pasien.

\section{DAFTAR PUSTAKA}

1. Stevy Dian Fitriani, Viabilitas Mycobacterium Leprae Pada Penderita Kusta Multibasiler yang Diobati Multi Drug Therapy (WHO) Dibandingkan Kombinasi Rifampisin, Ofloksasin dan Klaritromisin, Tesis: Universitas Hasanuddin Makassar;2011

2. Anonim. Profil Puskesmas Bandungsari Tahun 2013.Bandung;2013

3. Sofiarini, W. Pengetahuan, Sikap, dan Peran Keluarga dalam Upaya Penyembuhan Penderita Penyakit Kusta di Wilayah Kerja Puskesmas Kramatsari Kota Pekalongan. Sripsi. FKM Undip:Semarang;2004

4. Anonim. Modul Pelatihan Program kusta Untuk Unit Pelayanan Kesehatan (UPK), Dinas Kesehatan Provinsi Jawa Tengah;2012.

5. Westbrook, D., Kennerley, H, \& Kirk, J. An Introduction to Cognitive Behavior Therapy: Skills and Applications, Los Angeles: SAGE Publications;2007

6. Bedell, J. \& Lennox, S. S. Handbook for Communication and Problem-Solving Skilla Training: A Cognitive-Behavior Approach. New York: John Wiley \& Sons, Inc;2004

7. Alford, B. A., \& Beck, A. T. The Integrative Power of Cognitive Therapy. New York: Guilford Press; 1997

8. Matson, Jhonny L \& Thomas H. Ollendick. Enhancing Children's Social Skill: Assessment and Training. New York:Pergamon Press;1998

9. Putra B. Hubungani Antara Dukungan Sosial dengan Motivasi Untuk Sembuh pada Pengguna Napza di Rehabilitasi Madani Mental Health Care. Fakultas Psikologi.Jakarta: Universitas Islam Negeri Syarif Hidayatullah;2011

10.Kosasih, A. Faktor-faktor yang berhubungan dengan pengetahuan \& sikap kepala keluarga dan tokoh masyarakat tentang kusta di Kabupaten Kuningan, Propinsi Jawa Barat, tahun 1996. [Diakses tanggal 29 Desember 2013]. Diunduh dari http://www.digilib.ui.ac.id/opac/themes/libri/2detail.jsp?id=79721\&lokasi=lokal. 